\title{
海洋レーダーの出力流速の信頼度評価とデータ同化 \\ Reliability Evaluation and Assimilation of Coastal Current Data Measured by Ocean Rader
}

\author{
${\text { 西田修三 }{ }^{1} \cdot \text { 田尾雄喜 }}^{2} \cdot$ 柴田剛志 $^{3} \cdot$ 長谷川剛基 $^{2} \cdot$ 入江政安 $^{4}$ \\ 平澤充成 ${ }^{5} \cdot$ 藤原敏晴 $^{6} \cdot$ 上岡智志 ${ }^{7}$
Shuzo NISHIDA, Yuki TAO, Takeshi SHIBATA, Goki HASEGAWA, Masayasu IRIE Mitsunari HIRASAWA, Toshiharu FUJIWARA and Satoshi UEOKA

\begin{abstract}
A monitoring technique of surface currents using an ocean Doppler radar is in a practical stage, and the radars have been set up in some places in Japan as for the current and wave monitoring system. However, no information is provided about accuracy or reliability of the detected Doppler frequency and the output velocity. It is necessary to make a data processing routine to evaluate the reliability of output velocities. In this study, the Doppler spectrum characteristics when large errors have been detected were analyzed, and the reliability at the output velocity was evaluated using some indices. In addition, the assimilation of the currents in Osaka Bay was carried out using the radar data considering the reliability of the velocity data.
\end{abstract}

\section{1.はじめに}

海洋レーダーの表層流速測定技術は十分な実用段階に 達し，各地で流況モニタリングシステムとしての整備が 進んでいる（八木ら，1998；徳田ら，2000；坂井ら， 2004 ; 松山ら，2007）。大阪湾においてもDBF（Digital Beam Forming）方式のHF海洋レーダーが設置され，モ ニタリングが続けられている．時折生じるデータ欠損を 除けば，十分な精度で表層流速を捉えている（西田ら， 2005 ; 宮本ら，2007）.しかし，自動化された信号処理 アルゴリズムによりドップラーシフト周波数の検出と異 常值の欠損処理がなされているものの，検出された周波 数や出力された流速值の精度や信頼度に関する情報はな く, 信頼度の評価とその出力を含めたデータ処理ルーチ ンが必要と考えられる。さらに，データの信頼度指標が 付加された流速データの提供により，ょり信頼度の高い リアルタイムモニタリングが行えるばかりではなく, 数 值モデルへのデータ同化も可能になり, 流況の再現性と 予測精度が格段に向上する。そこで本研究では，大阪湾 流況観測システムのデータを用いて，エラー流速が生じ た場合のドップラースペクトルを解析し，その特性を表 す指標を抽出し，算定される表層流速の信頼度をその指 標を用いて評価することを試みた。さらに，得られた表 層流速を用いて大阪湾の同化シミュレーションを行うと

\begin{tabular}{|c|c|c|}
\hline \\
\hline \multicolumn{3}{|r|}{ 地球総合工学専攻 } \\
\hline 学生会 & & 大阪大学大学院 地球総合工学専攻 \\
\hline 正会員 & 修 (工) & （株）大林組 \\
\hline 正会員 & 博 (工) & 大阪大学大学院助教 地球総合工学専工 \\
\hline 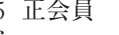 & 博 (工) & 国交省神戸港湾空港技術調查事務所 所長 \\
\hline & & 国交省神戸港湾空港技術調查事務所 課長 \\
\hline & & 名古屋港湾事務所 係長 \\
\hline
\end{tabular}

ともに，信頼度指標を考慮した同化計算も行い，その適 用性について検討を行った。

\section{2. 観測概要}

レーダーのローカル局は神戸市垂水区と淡路市久留麻 に設置され，観測領域は図-1に示すとおりである.

写真-1 はA局におけるアンテナ設置状況である。各口

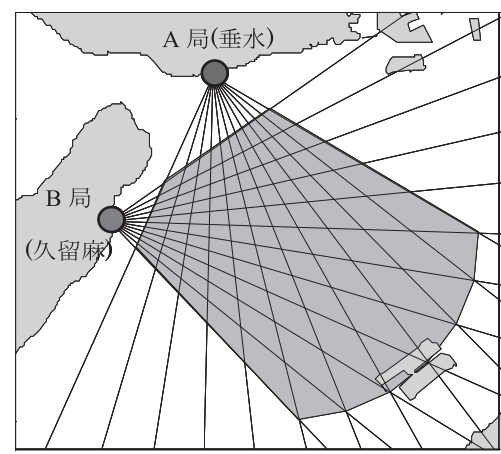

図-1 レーダー観測領域

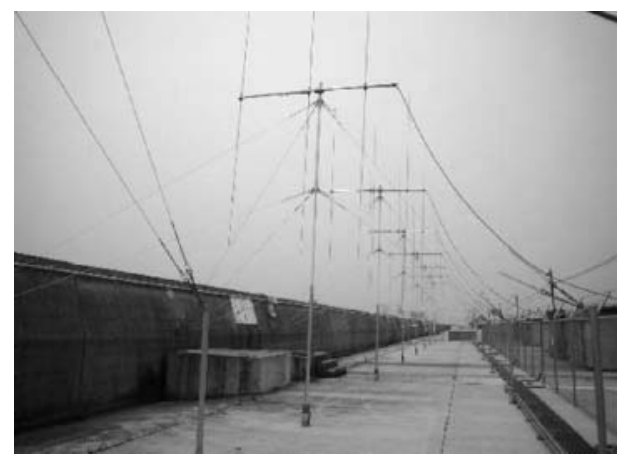

写真-1 アンテナ設置状況 
ーカル局は, アンテナ, 送受信装置, 制御用パソコンを 備え, 得られたデータは電話回線（ISDN回線）によっ て中央局に伝達される. 中央局では, 流況解析を行うと ともにローカル局の観測制御も行っている.

レーダーはDBF（Digital Beam Forming）方式のHF帯 レーダーであり, 観測時間間隔は 1 時間, 距離分解能 1 . $5 \mathrm{~km}$, ビーム間隔 $7.5^{\circ}$, 流速分解能約 $5 \mathrm{~cm} / \mathrm{s}$ である. 解析 には2007年と 2008 年のデータを使用した.

なお，2008年12月にはB局の堺市への移転に伴い観測 を一時停止し，2009年2月より新たな観測領域で観測を 再開している。

\section{3. 観測結果}

\section{（1）エラーデータの抽出}

レーダーシステムでは，異常な流速が算出されたり， 観測域の一部または全域で流速データが欠損するなど, 流速が正しく出力されない場合がある. 原因としては, 観測機器のトラブルや台風など荒天によってデータ欠損 が生じた場合，スペクトルの一次散乱ピークが精度良く 検出できず視線方向流速に大きな誤差が生じた場合など が考えられる．図-2は異常な流速が出力された場合の一 例である. 関空沖および明石海峡前面で大きな流速值が 出力されている.

2007 年各季（1月，4月，8月，10月）において，異常 な流速が出力された頻度と流速欠損が生じた頻度を表-1 に示す。ただし，流速の一部欠損と異常な流速の算出が

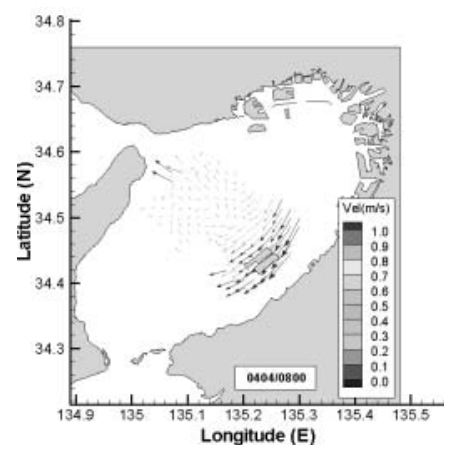

図-2 異常流速の出力例

表-1 流速欠損と異常流速出力の発生頻度

\begin{tabular}{c|c|c|c|c|c}
\hline 観測月 & 1月 & 4 月 & 8月 & 10 月 & 総計 \\
\hline データ総数 & 744 & 720 & 744 & 744 & 2952 \\
\hline 全データ欠損数 & $\begin{array}{c}92 \\
(12.4 \%)\end{array}$ & $\begin{array}{c}2 \\
(0.3 \%)\end{array}$ & $\begin{array}{c}3 \\
(0.4 \%)\end{array}$ & $\begin{array}{c}6 \\
(0.8 \%)\end{array}$ & $\begin{array}{c}103 \\
(3.5 \%)\end{array}$ \\
\hline 一部データ欠損数 & $\begin{array}{c}40 \\
(5.4 \%)\end{array}$ & $\begin{array}{c}15 \\
(2.1 \%)\end{array}$ & $\begin{array}{c}23 \\
(3.1 \%)\end{array}$ & $\begin{array}{c}32 \\
(4.3 \%)\end{array}$ & $\begin{array}{c}110 \\
(3.7 \%)\end{array}$ \\
\hline 異常流速出力数 & $\begin{array}{c}48 \\
(6.5 \%)\end{array}$ & $\begin{array}{c}64 \\
(8.9 \%)\end{array}$ & $\begin{array}{c}42 \\
(5.6 \%)\end{array}$ & $\begin{array}{c}50 \\
(6.7 \%)\end{array}$ & $\begin{array}{c}204 \\
(6.9 \%)\end{array}$ \\
\hline
\end{tabular}

同時に発生している場合は両方にカウントしている.こ のように異常流速の出力や流速の欠損は季節を問わず発 生し，10\%以下ではあるが無視できない量である.

\section{（2）エラー要因とスペクトル特性}

レーダー観測ではビームが直交したとき，算出される 流速の誤差は最小を示し, 交差角が $90^{\circ}$ からずれるに従 い誤差は大きくなり, 視線方向流速誤差の $1 / \sin \alpha$ 倍の誤 差が生じる（Nadaiら，2006）。この交差角に依存した誤 差（1/sin $\alpha ）$ の分布を図-3に示す. 局から遠方の関空島 付近と局近傍において大きな誤差が生じていることがわ かる.

このような計測システム自体が有する誤差の発生要因 の他に，受信信号のスペクトル異常も大きな流速誤差の 発生要因となる。通常, 受信信号のスペクトルには, 被 測定域における視線方向流速に対応した一次散乱ピーク が生じる (図-4). しかし, 観測セル内の流れの非定常性 や非一様性, 雑音レベル, さらには電波の反射や干渉な どにより，一次散乱ピークが検出できなかったり，ある いは検出できたとしても信頼性の低い視線方向流速が算 出されることになる.

ここではエラーデータに多く見られた，(1)一次散乱ピ ーク以外にスペクトルピークが出現する場合 (図-5), (2) 一次散乱ピークがノイズに埋もれる場合 (図-6), (3)一次 散乱ピークが急峻でない場合（図-7）の3ケースについ て解析を行う.

(1)のケースは，同時刻に他局で計測を行った場合など にみられる干渉や, 対岸や船舶からの反射等によって発 生するが, 明らかに一次散乱ピークとは異なる周波数に ピークが出現し, さらに, レンジ方向にピーク周波数の 変化が見られないなどの特性を有し, 比較的除去が可能 なエラーである。

(2)のケースは, Bragg散乱強度が低い場合やノイズレ ベルが高い場合に生じ, スペクトルの一次散乱ピークが ノイズに埋もれてしまい, 一時散乱ピークよりエネルギ 一の大きなノイズを一時散乱ピークとして誤検出してし

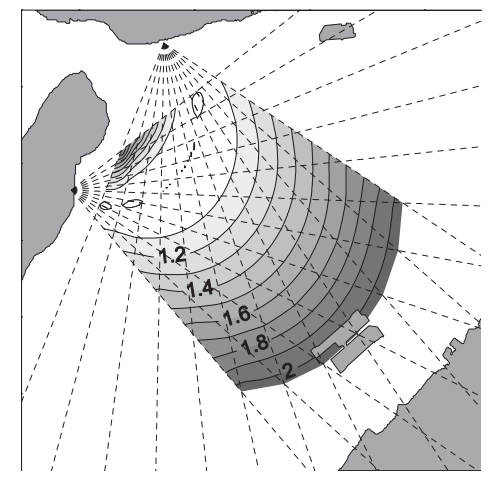

図-3 交差角に依存した誤差（1/sin $\alpha ）$ の分布 
まう。現観測システムでは, 出力流速の信頼性を考慮し て一次散乱ピークのエネルギーとノイズの平均エネルギ 一の比であるSNR（信号雑音比；Signal-Noise-Ratio）が $10 \mathrm{~dB}$ 以下の場合は一次散乱ピークを検出せず，視線方向 流速を欠損としている。図-4と図-6のSNRは，それぞれ $30.1 \mathrm{~dB} ， 14.2 \mathrm{~dB}$ であった。

一次散乱ピークが急峻でない(3)のケースでは，ピーク は検出されるが，算出された視線方向流速の信頼度が著 しく低下する場合がある。一次散乱がノイズに埋もれて いない場合でも，一次散乱ピークが急峻でなく平坦化し た場合や，ピークが双峰化した場合には，ピーク周波数

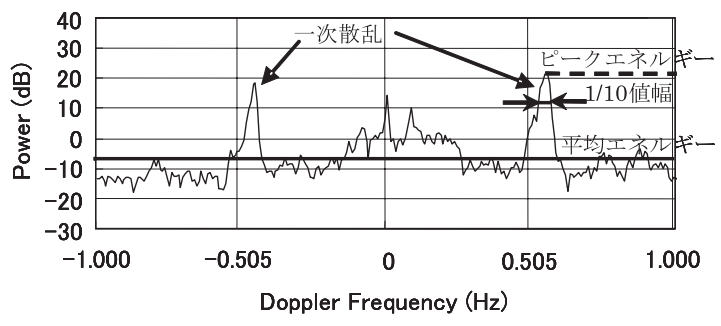

図-4 良好なスペクトルの例

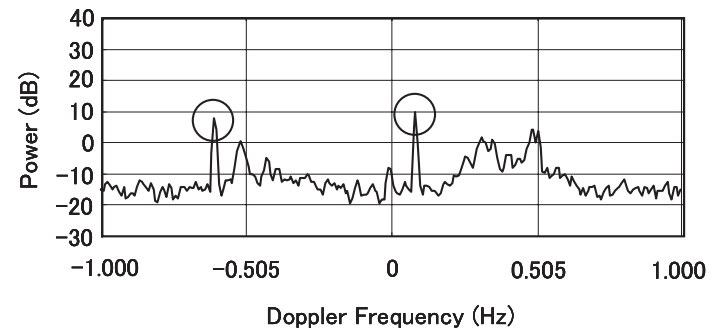

図-5 擬スペクトルピークが現れた場合（ケース(1)

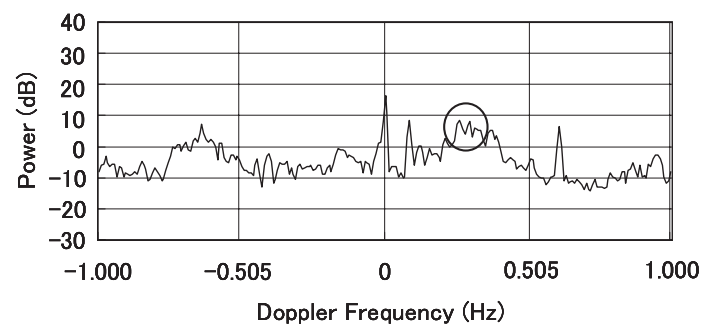

図-6 ピークがノイズに埋もれている場合（ケース(2)）

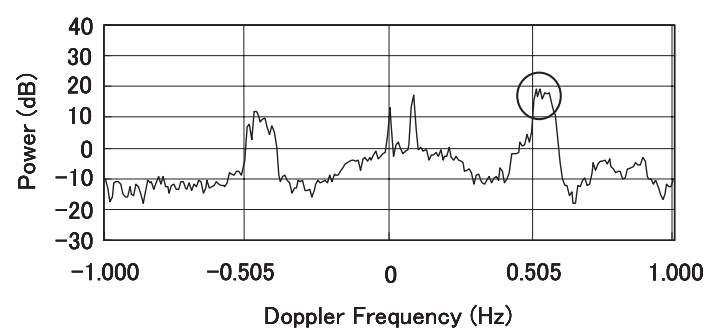

図-7 ピークが急峻でない場合（ケース(3)）
の検出精度が低下し，出力流速に誤差が発生する．この 原因としては，流れの非定常性や非一様性が挙げられる (宮本，2007).

\section{4. 流速データの信頼度評価}

\section{（1）信頼度指標}

除去可能な擬スペクトルピークが現れる(1)の場合を除 いた残りの2ケースについて, 出力される流速の信頼度 を，スペクトル特性を表す指標を用いて評価した。

まず，一次散乱ピークがノイズに埋もれている場合の 信頼度を評価するために，SNRに代えて計算が容易な， 一次散乱ピークと全 $\mathrm{dB}$ 平均エネルギーの比で表される指 標PAR（Peak-Average-Ratio）を考える（図-4参照）. PAR CNRには高い相関が認められ，ノイズレベルの評 価にSNRの代わりに計算処理の簡単なPARを指標として 用いることが十分可能であることがわかったＰARが $20 \mathrm{~dB}$ 以下でピーク検出のエラー頻度が増したため, $\mathrm{PAR} \geqq 20 \mathrm{~dB}$ で信頼度=1 として, PAR $<20 \mathrm{~dB}$ では図-8に 示す線形の関係で信頼度を表現した。こうすることで信 頼度を 0 〜 の数值で評価できる。一例として，スペク トルより算出されたPARの空間分布と, このPARより評 価された信頼度分布を図-9に示す。観測時の海象等の影 響を受けて空間的に大きく変化していることがわかる.

次に，一次散乱ピークが急峻でない場合の信頼度を評 価するために，一次散乱ピークの $1 / 10$ のエネルギーの周 波数幅を示す $1 / 10$ 值幅 $(-10 \mathrm{~dB}$ 幅) という指標を考える (図-4参照)。観測データを基に決定した図-10に示す関係 を用いて信頼度を表現した。図-9と同じ観測デー夕を用 いて $1 / 10$ 值幅と信頼度の空間分布を求めた結果を図-11

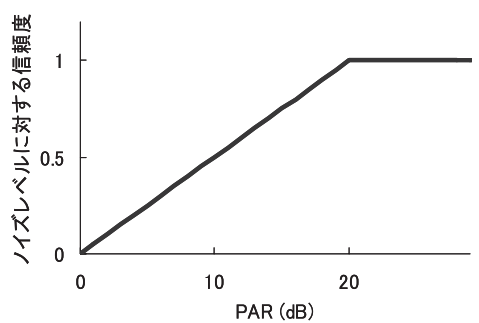

図-8ＰARによる信頼度評価

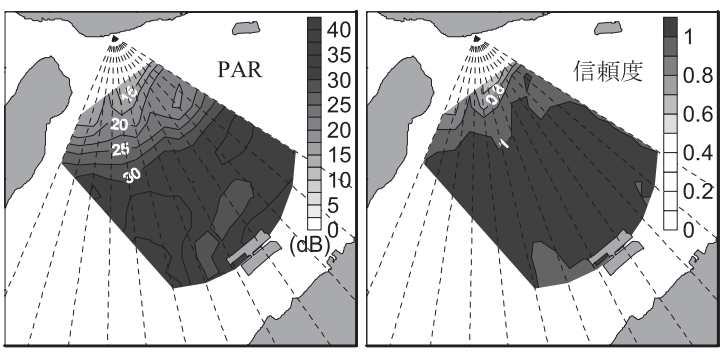

図-9 PAR と信頼度の空間分布（2008/12/7 21:00 A局） 


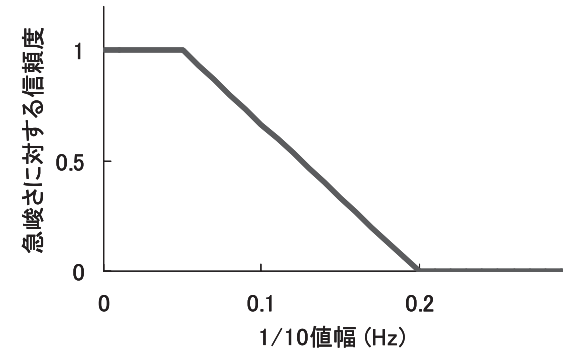

図-10 1/10值幅による信頼度評価

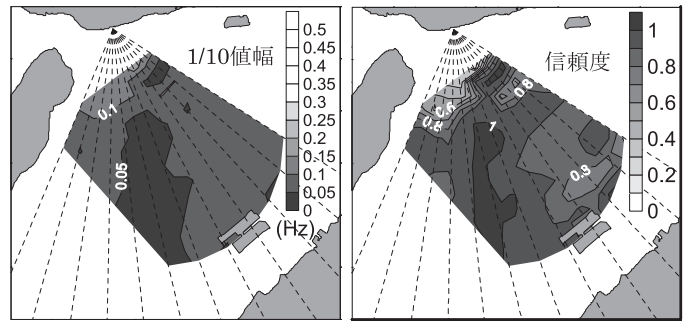

図-11 1/10值幅と信頼度の空間分布（2008/12/7 21:00 A局）

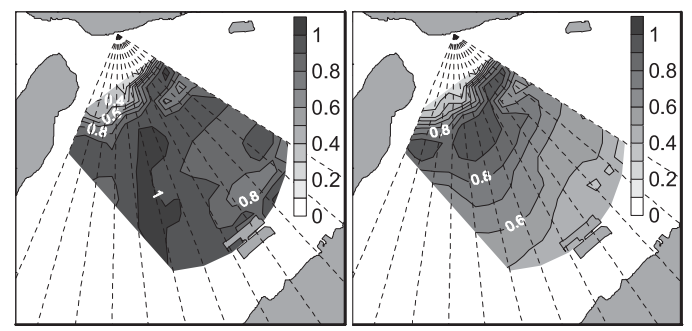

図-12 統合化された信頼度の空間分布 （右図：交差角による信頼度を考慮）

に示す．明石海峡からの強い流れの影響を直接受ける海 域で $1 / 10$ 值幅の值が大きく，信頼度が低下していること がわかる.

\section{（2）信頼度評価手法}

上記 $2 つ の$ 指標の統合化，さらに図-3に示した交差角 誤差も含めた統合化を行い，流速の信頼度を一つに統合 化された指標で表現することを試みた。交差角誤差につ いてはその逆数を信頼度として評価した．統合化には幾 つかの方法があるが，ここでは各指標の信頼度の相乗積 をもって出力流速の信頼度 RI とした. 交差角誤差を加味 しない場合と加味した場合についてそれぞれ図-12に示 した、スペクトル特性から信頼度が低いと評価された明 石海峡前面海域においては, 統合化された信頼度もやは り低く, 流速デー夕の解析に注意を要することがわかる.

ここで定義した信頼度と実測流速の精度との定量的関 係が現時点では不明である，今後，信頼度の評価と検証 に向けた調查・解析が必要と考えている.

\section{5. データ同化}

観測データを用いて同化シミュレーションを行う。海
洋レーダーのデータを用いたデー夕同化の研究としては, モントレー湾に扔けるLewisら（1998）の研究，大阪湾 に打ける石塚ら（2000）の研究，伊勢湾に打ける坂井ら （2003）の研究等がある. 同化手法としては, Blending法, Nudging 法, カルマンフィルター法, Adjoint法など種々 あるが，ここでは緩和法の一種である Nudging法を用い たデー夕同化を行う.

\section{(1) 同化手法}

同化計算期間は，2008年 11月 23日〜 12月 7 日までの 助走期間を含む 25 日間である. 残差流については計算終 了前 15 日間のデー夕を用いて解析を行った. HFレーダ 一の観測值が提供される毎正時ごとに表層流速值を与 え，各計算ステップでは内挿值を用いてデー夕同化を行 った。流動計算には3 次元流動モデルROMSを使用し, 潮位の境界条件は播磨灘の江井と高砂, 紀淡海峡の粟津 と海南において計算日の潮位を与えた。その他，塩分 . 水温の初期条件・境界条件及び河川条件・日射条件は関 係機関で観測された秋季の観測デー夕等を参考にして与 えた.

Nudging 係数は流れの計測誤差や時空間スケール等に 依存するが，その定式化は難しい。ここではLewisら （1998）や石塚ら（2000）の研究成果を参考に，10-2の定 数を与えて同化計算を行った. 流速定義格子において計 算值 $U_{\mathrm{c}}$ と観測值 $U_{\mathrm{o}}$ との差を Nudging 係数 $G$ を用いて体積 要素 $\Delta V$ に対して, $G \times \Delta V \times\left(U_{\mathrm{o}}-U_{\mathrm{c}}\right)$ の運動量補正を 行った.

また，前章の統合化された信頼度（図-12右）をNudging 係数に乗じて, $G^{\prime}=R I \times G$ として流速デー夕の信頼度を 加味した同化計算も行った。ただし, 現時点では信頼度 評価の計算が自動化されていないため，計算は15日間の 同化計算の最終日 1 日間（2008年12月 7日）にのみ適用 し，その効果を検証した。

\section{(2) 計算結果}

図-13は，気象デー夕より予測された風応力を海面に 与えた場合と，さらにレーダー観測域においてデー夕同 化を行った場合の比較である. 表層 $1 \mathrm{~m}$ の残差流（15日 間平均流）を示している。デー夕同化により明石海峡付 近では $10 \mathrm{~cm} / \mathrm{s}$ 以上の流速変化が生じている，また，同化 の影響域は同化範囲外にも大きく拡がり, 大阪湾東岸恒 流帯にも影響が及んでいることがわかる.

図-14は, Nudging 係数に信頼度を加味した場合の計算 結果との比較である. 同化計算の最終 1 日について Nudging 係数を $10^{-2}$ のまま計算した結果と，統合化された 信頼度を加味したNudging係数を用いた場合の比較であ る. 関空島北部海域や同化範囲外の明石海峡前面海域に おいて流速の大きな変化がみられ，信頼度を考慮するこ とで再現性に大きな違いが現れることがわかった。 

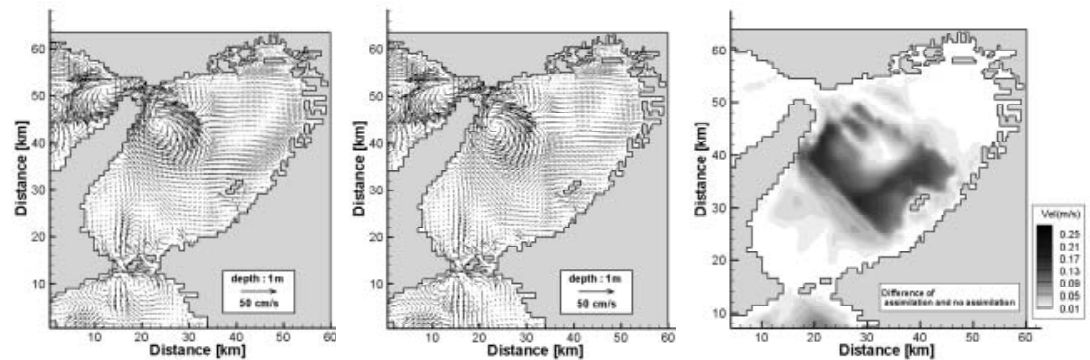

図-13 表層 $1 \mathrm{~m}$ の 15 日間平均流（左：同化なし, 中：同化あり, 右：偏差量）
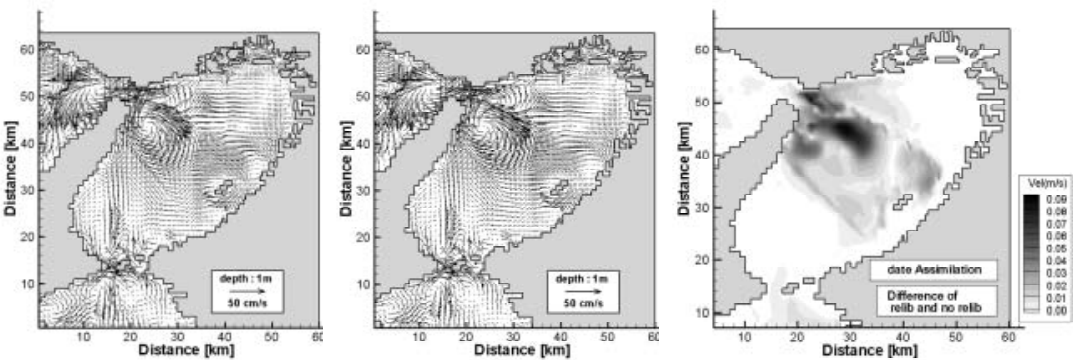

図-14 表層 $1 \mathrm{~m}$ の日平均流（左：信頼度考慮なし，中：信頼度考慮，右：偏差量）

\section{6. おわりに}

本研究で得られた主たる結果は以下のとおりである.

（1）エラーデータの抽出と発生頻度の解析を行った結果, 異常流速值の出力頻度は観測数の $10 \%$ 以下ではあった が無視できない量であった。

（2）エラーピークの出現, $\mathrm{S} / \mathrm{N}$ 比の低下，一時散乱ピ ークの双峰化・平坦化など，計測されたスペクトル特 性からエラー要因の分類を行うことが可能であった.

（3） $\mathrm{S} / \mathrm{N}$ 比を表す実用的な指標として，ピーク／平均 エネルギー比（PAR）を用いて信号特性を評価するこ とができた。

（4）ピークの双峰化・平坦化の指標として，1/10值幅 （－10dB幅）を用いて信号特性を評価することがで きた。

（5）これらの指標を用いてデータの信頼度を指数化し, その空間分布特性の解析を行った。 また，信頼度の統 合化手法についても検討を行い一手法の提案を行 つた。

（6） 3 次元流動モデルへのデータ同化手法について, Nudging 法を用いた試行計算を行った結果，信頼度の 考慮により再現結果に差異が生じ，デー夕信頼度の評 価と導入の必要性が示唆された.

\section{参 考 文 献}

石塚正秀・松田真人・中辻啓二（2000）：海洋レーダによる表 層流速デー夕の3次元流動計算への同化に関する研究，水
工学論文集, 第44巻, pp. 1167-1172.

坂井伸一 (1999)：鉛直 1 次元同化モデルによるパラメー夕評 価の試み，水工学論文集，第43巻, pp. 839-844.

坂井伸一. 平口博丸 - 松山昌史 - 坪野考樹 - 森 信人 (2003) :

DBF 海洋レーダを用いたデータ同化による3次元沿岸流動 解析の試み, 水工学論文集, 第47巻, pp. 1309-1314.

坂井伸一・松山昌史・坪野考樹 - 森 信人 - 中辻啓二 ・西田 修三・中池悦郎・谷川陽祐（2004）：DBFレーダによる沖 ノ瀬環流域の広域流動観測，海岸工学論文集，第 51 巻, pp. 1416-1420.

多田彰秀 - 竹之内健太 - 坂井伸一 - 染矢真作 - 水沼道博 - 中 村武弘（2006）：DBF 海洋レーダによる諫早湾湾口部の流 況観測, 海岸工学論文集, 第 53巻, pp. 356-360.

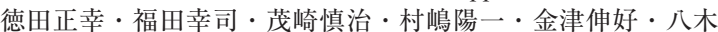
宏（2000）：VHF海洋レーダ観測による播磨灘の表層流特 性, 海岸工学論文集, 第47巻, pp. 1366-1370.

西田修三・中辻啓二・宮本豊尚 - 清水隆夫 ·坂井伸一 - 松山 昌史・坪野孝樹（2005）：DBF海洋レーダーによる大阪湾 奥部の流況観測と波浪観測への応用，海岸工学論文集， 第 52 巻, pp. 1441-1445.

松山昌史・吉井 匠・坪野考樹 - 坂井伸一・多田彰秀 - 水沼 道博（2007）：VHF帯のDBF 海洋レーダによる安定した 長期リアルタイム観測とその有効性，海岸工学論文集， 第 54巻, pp. 1441-1445.

宮本豊尚・西田修三（2007）：海洋レーダのスペクトルに及ほ す海象の影響, 海岸工学論文集, 第 54巻, pp. 1456-1460.

八木 宏・日向博文・田岡幸司・久木幸二・灘岡和夫 (1998): 短波海洋レーダに基づく冬季日本海能登半島沖の流況解 析, 海岸工学論文集, 第45巻, pp.416-420.

Lewis, J. K., I. Shuman, and A. F. Blumberg (1998): Assimilation of Doppler radar current data into numerical ocean models, Continental Shelf Research 18, pp.541-559.

Nadai, A. (2006): Model analysis of influence of wave-current interaction on current measurement of HF ocean surface radar for isolated eddy and upwelling, Journal of Geophysical Research, vol.111, C10012. 